\title{
Spontaneous incorporation of gold in palladium-based ternary nanoparticles makes durable electrocatalysts for oxygen reduction reaction
}

Deli Wang ${ }^{1}$, Sufen Liu ${ }^{1}$, Jie Wang ${ }^{1}$, Ruoqian Lin ${ }^{2}$, Masahiro Kawasaki ${ }^{3}$, Eric Rus ${ }^{4}$, Katharine E. Silberstein ${ }^{4}$, Michael A. Lowe ${ }^{4}$, Feng Lin ${ }^{5}$, Dennis Nordlund ${ }^{6}$, Hongfang Liu' ${ }^{1}$ David A. Muller 7,8 , Huolin L. Xin ${ }^{2}$ $\&$ Héctor D. Abruña 4

Replacing platinum by a less precious metal such as palladium, is highly desirable for lowering the cost of fuel-cell electrocatalysts. However, the instability of palladium in the harsh environment of fuel-cell cathodes renders its commercial future bleak. Here we show that by incorporating trace amounts of gold in palladium-based ternary $\left(\mathrm{Pd}_{6} \mathrm{CoCu}\right)$ nanocatalysts, the durability of the catalysts improves markedly. Using aberration-corrected analytical transmission electron microscopy in conjunction with synchrotron X-ray absorption spectroscopy, we show that gold not only galvanically replaces cobalt and copper on the surface, but also penetrates through the $\mathrm{Pd}-\mathrm{Co}-\mathrm{Cu}$ lattice and distributes uniformly within the particles. The uniform incorporation of Au provides a stability boost to the entire host particle, from the surface to the interior. The spontaneous replacement method we have developed is scalable and commercially viable. This work may provide new insight for the large-scale production of non-platinum electrocatalysts for fuel-cell applications.

\footnotetext{
${ }^{1}$ Key laboratory of Material Chemistry for Energy Conversion and Storage (Huazhong University of Science and Technology), Ministry of Education, Hubei Key Laboratory of Material Chemistry and Service Failure, School of Chemistry and Chemical Engineering, Huazhong University of Science and Technology, Wuhan 430074, China. ${ }^{2}$ Center for Functional Nanomaterials, Brookhaven National Laboratory, Upton, New York 11973, USA. ${ }^{3}$ JEOL USA, Inc., Peabody, Massachusetts 01960, USA. ${ }^{4}$ Department of Chemistry and Chemical Biology, Cornell University, Ithaca, New York 14853, USA. ${ }^{5}$ Energy Storage and Distributed Resources Division, Lawrence Berkeley National Laboratory, Berkeley, California 94720, USA. ${ }^{6}$ Stanford Synchrotron Radiation Lightsource, SLAC National Accelerator Laboratory, Menlo Park, California 94025, USA. ${ }^{7}$ School of Applied and Engineering Physics, Cornell University, Ithaca,

New York 14853, USA. ${ }^{8}$ Kavli Institute at Cornell for Nanoscale Science, Cornell University, Ithaca, New York 14853, USA. Correspondence and requests for materials should be addressed to D.W. (email: wangd181125@hust.edu.cn) or to H.L.X. (email: hxin@bnl.gov) or to H.D.A. (email: hda1@cornell.edu).
} 
P t-based nanoparticles have been extensively studied as electrocatalysts for the oxygen reduction reaction (ORR) in both acid and alkaline media ${ }^{1-7}$. However, the high cost and the limited reserve of Pt hinder the widespread deployment of fuel-cell technologies. Numerous strategies have been employed including developing new structures and morphologies for Pt-based nanocatalysts ${ }^{3,8-13}$, Pt monolayer decorated nanoparticles ${ }^{14,15}$, other platinum group nanomaterials ${ }^{16-19}$, as well as non-precious-metal nanoparticles ${ }^{16,20-24}$. Among these alternatives, Pd is very attractive because it is much more abundant and less expensive than Pt. However, the ORR activity of pure Pd in acid is much lower than that of Pt. Previous studies have focused on alloying Pd with $3 d$ transition metals, such as $\mathrm{Fe}^{25}, \mathrm{Co}^{14}, \mathrm{Ni}^{26}, \mathrm{Cu}^{27}$ and others, resulting in a significant improvement in catalytic activity. Moreover, the activity of Pd-based binary nanoparticles can be further enhanced by adding a third element ${ }^{28}$. In spite of that, Pd-based catalysts undergo fast degradation as ORR cathodes under regular cycling conditions. Previous studies have shown that these catalysts can be stablized by galvanically replacing the surface atoms with $\mathrm{Pt}^{14,29}$, which simultaneously increases Pt usage.

In this study, we show that Au atoms can penetrate the bulk lattice of $\mathrm{Pd}_{6} \mathrm{CoCu}$ nanoparticles and spontaneously replace Co and $\mathrm{Cu}$ atoms in the interior of the nanoparticles through galvanic replacement reactions. This effect allows the uniform incorporation of trace amounts of $\mathrm{Au}$ in $\mathrm{Pd}_{6} \mathrm{CoCu}$ nanoparticles, which enhances the long-term stability of the electrocatalyst for the ORR. We also show that there $\mathrm{a}$ is much smaller displacement (ca. $25 \mathrm{mV}$ ) in the half-wave potential for $\mathrm{Au}-\mathrm{Pd}_{6} \mathrm{CoCu}$ nanoparticles over 10,000 voltage cycles in $\mathrm{O}_{2}$-saturated $0.1 \mathrm{M}$ $\mathrm{HClO}_{4}$ solution, compared with a $54-\mathrm{mV}$ negative potential shift for $\mathrm{Pd}_{6} \mathrm{CoCu}$ nanoparticles without $\mathrm{Au}$ incorporation after only 1,000 cycles in $\mathrm{O}_{2}$-saturated $0.1 \mathrm{M} \mathrm{HClO}_{4}$ solution. More importantly, PEMFC single-cell performance using a $\mathrm{Au}-\mathrm{Pd}_{6} \mathrm{CoCu} / \mathrm{C}$ cathode electrocatalyst exhibits a maximum power-density loss of about $21 \%$ after a 100 -h stress test at $80^{\circ} \mathrm{C}$, which is dramatically better than a Au-free catalyst.

\section{Results}

Synthesis and charaterization of $\mathrm{Pd}_{6} \mathrm{CoCu} / \mathrm{C}$ nanoparticles. $\mathrm{Pd}_{6} \mathrm{CoCu}$ nanoparticles supported on Vulcan XC-72 carbon $\left(\mathrm{Pd}_{6} \mathrm{CoCu} / \mathrm{C}\right)$ were synthesized using an impregnation reduction method followed by high temperature heat-treatment as reported previously $y^{8,14,30}$. The crystal structures of the particles were characterized by X-ray diffraction (Supplementary Fig. 1). $\mathrm{Pd} / \mathrm{C}, \mathrm{Pd}_{3} \mathrm{Cu} / \mathrm{C}$ and $\mathrm{Pt}_{3} \mathrm{Co} / \mathrm{C}$ nanoparticles are also shown for comparison. The X-ray diffraction patterns suggest a face-centered cubic structure. The peak positions of the bi-/tri- metallic nanoparticles shift to higher angles, as anticipated, compared to pure $\mathrm{Pd} / \mathrm{C}$. The angular shifts indicate alloy formation between $\mathrm{Pd}$ and $\mathrm{Co} / \mathrm{Cu}$, and reflect a lattice contraction, which is caused by the incorporation of smaller atoms, $\mathrm{Co} / \mathrm{Cu}$, into the $\mathrm{Pd}$ face-centered cubic lattice. The surface composition of the particles was determined by X-ray photoelectron spectroscopy (XPS) (Supplementary Fig. 2). For the $\mathrm{Pd}_{6} \mathrm{CoCu} / \mathrm{C}$ sample, there is almost no Co2p signal, while two distinct $\mathrm{Cu} 2 p$ peaks are evident. This suggests that $\mathrm{Cu}$ is likely distributed closer to the surface of the particle than Co as illustrated in Fig. 1.

To directly measure the structure and chemical composition of the nanoparticles at the atomic scale, we used aberrationcorrected scanning transmission electron microscopy (STEM) in conjunction with electron energy loss spectroscopy (EELS) to characterize the samples (Fig. 2). The $\mathrm{Pd}_{6} \mathrm{CoCu} / \mathrm{C}$ nanoparticles appear to be uniformly distributed on the carbon support with an a
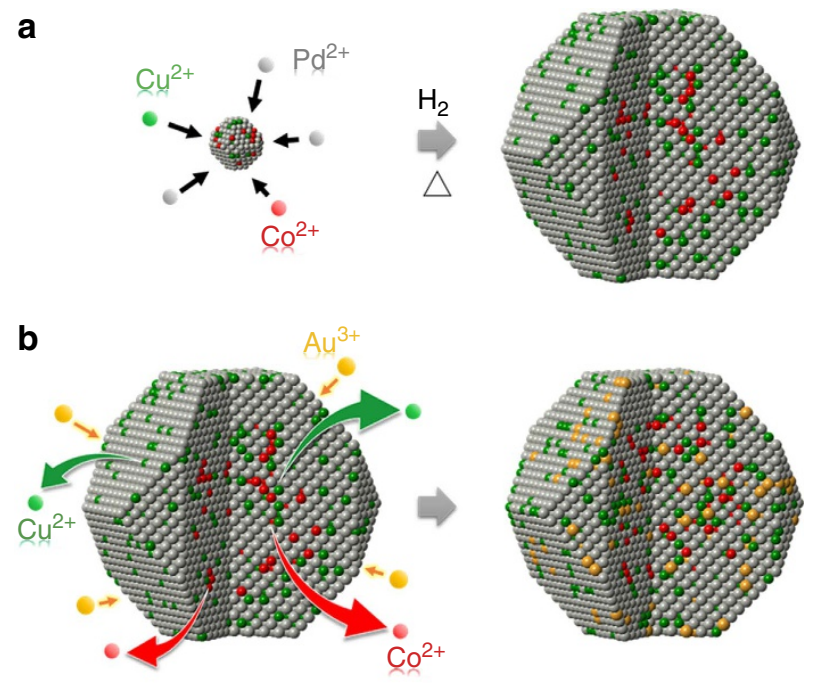

Figure 1 | Diagrammatic illustration of the synthetic strategy of nanoparticles. Schematic illustration of the formation of $\mathrm{Pd}_{6} \mathrm{CoCu} / \mathrm{C}$ (a) and $\mathrm{Au}-\mathrm{Pd}_{6} \mathrm{CoCu} / \mathrm{C}$ (b).

average particle size of $7.5 \mathrm{~nm}$, consistent with the particle size calculated from X-ray diffraction (Supplementary Fig. 3 and Supplementary Table 1). Figure 2a,b show the annular dark-field (ADF)-STEM images, which reflect the atomic mass contrast of the materials, and EELS elemental mapping of the as-prepared $\mathrm{Pd}_{3} \mathrm{Cu} / \mathrm{C}$ and $\mathrm{Pd}_{6} \mathrm{CoCu} / \mathrm{C}$ nanoparticles, respectively. For $\mathrm{Pd}_{3} \mathrm{Cu} /$ $\mathrm{C}$ nanoparticles, the EELS spectroscopic images in Fig. 2a indicate a uniform elemental distribution of $\mathrm{Pd}$ and $\mathrm{Cu}$ from the particle's interior to the surface. There is no surface segregation between $\mathrm{Pd}$ and $\mathrm{Cu}$. This is in contrast to our previously reported $\mathrm{Pd}_{3} \mathrm{Co} / \mathrm{C}$ nanoparticles that had a $\sim 1$-nm-thick Pd-rich shell on the particles surface ${ }^{14,30}$.

Figure $2 \mathrm{~b}$ shows the ADF-STEM images and EELS elemental maps of $\mathrm{Pd}_{6} \mathrm{CoCu} / \mathrm{C}$ nanoparticles. There is no phase segregation in the composite maps of $\mathrm{Pd}$ and $\mathrm{Cu}$, which is the same as in $\mathrm{Pd}_{3} \mathrm{Cu} / \mathrm{C}$ nanoparticles. However, a Pd-rich shell was observed for the composite maps of Pd and Co. To quantify the surface and subsurface chemical composition with atomic-scale resolution, we investigated a single facet of a $\mathrm{Pd}_{6} \mathrm{CoCu}$ particle (Fig. 2c). The chemical maps in Fig. $2 \mathrm{c}$ clearly show that there is a $\sim 1-\mathrm{nm}$ thick Pd-Cu-rich layer present on the surface of the $\mathrm{Pd}_{6} \mathrm{CoCu} / \mathrm{C}$ nanoparticle. This is consistent with the low Co $2 p$ signal in XPS, as the $\mathrm{Pd}-\mathrm{Cu}$-rich shell blocks the photoelectrons generated from Co $2 p$ core levels.

The difference in the segregation behaviour between $\mathrm{Pd}-\mathrm{Cu}$ and Pd-Co is likely a result of two contributions. First, as has been calculated by Nørskov et al. ${ }^{31}$ and Wang et al..$^{32}$, the surface segregation energy between $\mathrm{Pd}$ and $\mathrm{Co}$ is much higher than between $\mathrm{Pd}$ and $\mathrm{Cu}$. This suggests that there would be a much stronger driving force for surface segregation in $\mathrm{Pd}-\mathrm{Co}$ than in $\mathrm{Pd}-\mathrm{Cu}$ nanoparticles. Second, the differences in the gas-adsorption energies of two metals can induce surface segregation $^{33}$. The particles were heat-treated in a flowing stream of hydrogen. The fact that hydrogen binds strongly to $\mathrm{Pd}$ surfaces and can even be stored in Pd lattices, suggests that Pd can be enriched at the surface, thus pushing other elements away from the surface.

Synthesis and charaterization of $\mathrm{Au}-\mathrm{Pd}_{6} \mathrm{CoCu} / \mathrm{C}$ nanoparticles. The Au cluster-modified $\mathrm{Pt} / \mathrm{C}$ nanoparticles, prepared 
a
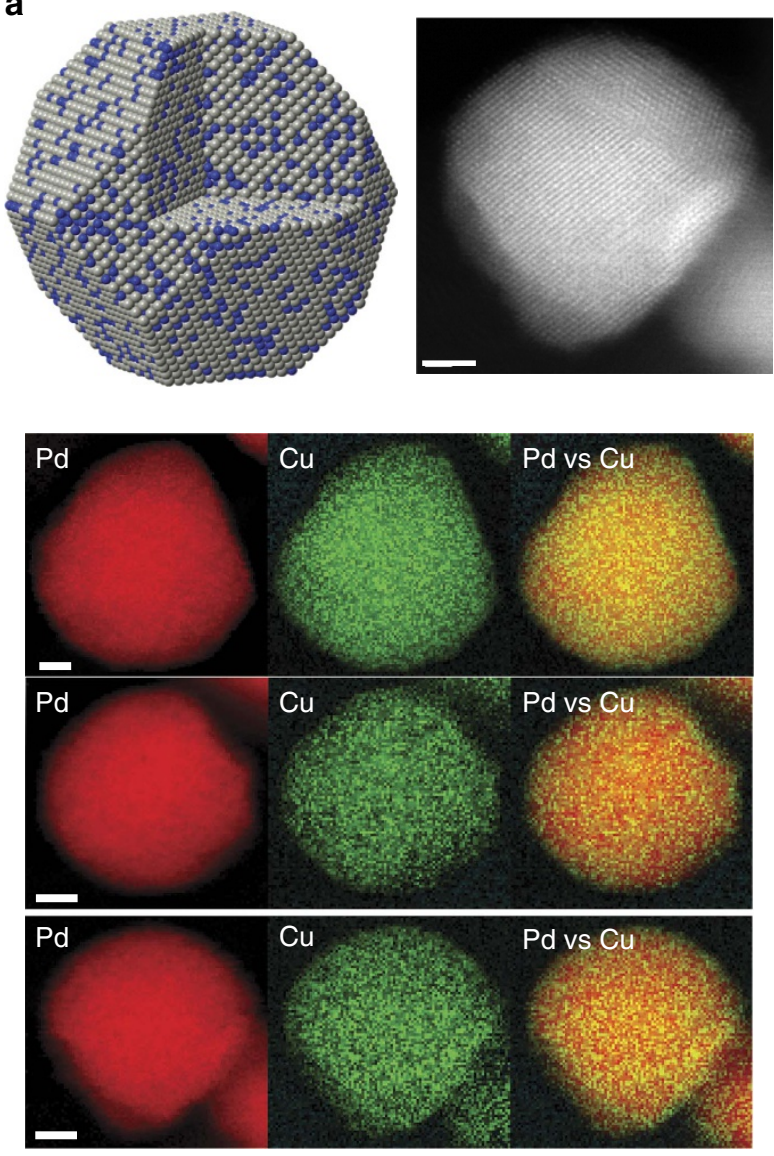

b
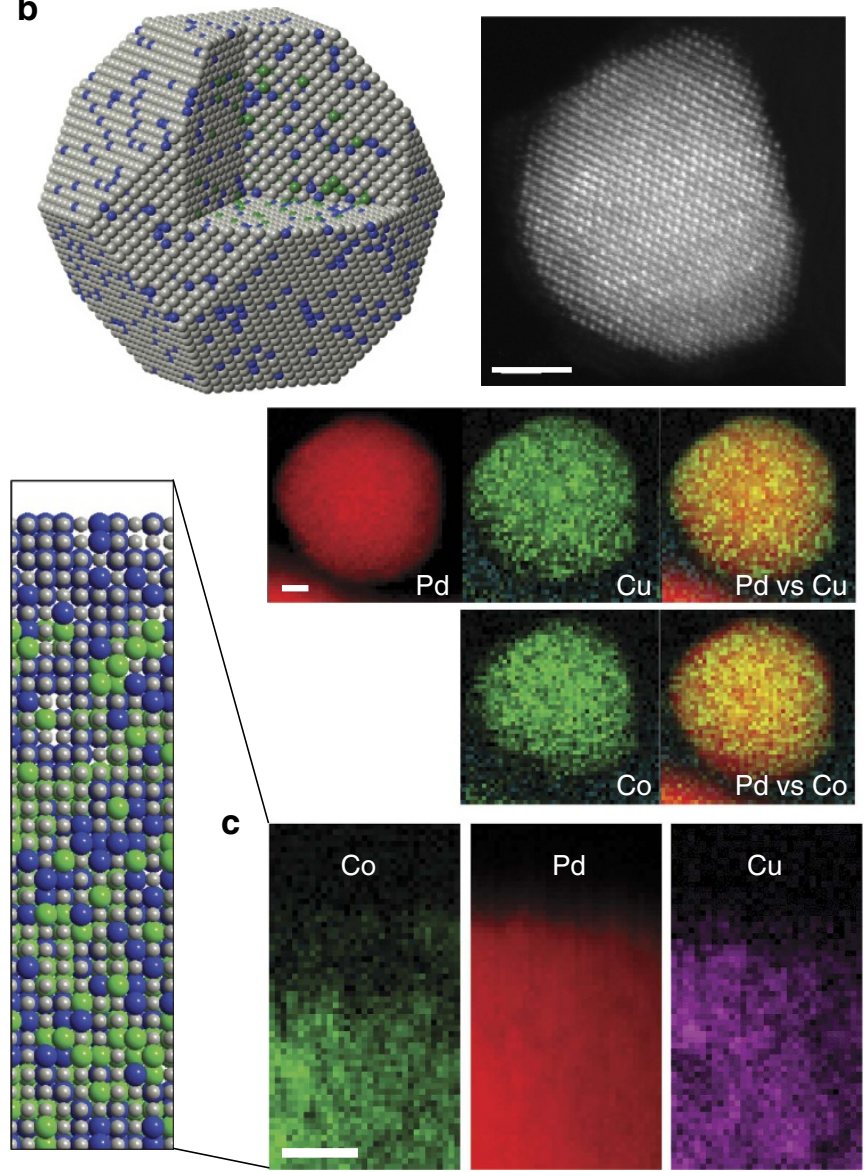

Figure 2 | ADF-STEM images and elemental mapping. Modelled structure, ADF-STEM image, and 2D EELS maps of each element and composites of $\mathrm{Pd} 3 \mathrm{Cu} / \mathrm{C}(\mathbf{a})$ and $\mathrm{Pd} 6 \mathrm{CoCu} / \mathrm{C}(\mathbf{b})$. Scale bar, $2 \mathrm{~nm}$. (c) Elemental maps of a $\mathrm{Pd}_{6} \mathrm{CoCu}$ particle's surface and subsurface volume extracted from an atomicscale EELS map. Scale bar, $1 \mathrm{~nm}$.

by the $\mathrm{Cu}$ under-potential deposition method, have been reported to significantly enhance the stability of $\mathrm{Pt} / \mathrm{C}$ for the ORR ${ }^{34}$. Recently, Stamenkovic et al. reported that Au-stabilized Pt-AuNi nanoparticles with a multilayer profile of Ni@Au@PtNi could endure extended durability testing ${ }^{35}$. Adzic et al. showed that structurally ordered intermetallic AuPdCo nanoparticles exhibited increased activity and much better durability for the $\mathrm{ORR}^{36}$.

Inspired by previous studies, we used a galvanic replacement method to deposit $\mathrm{Au}$ on $\mathrm{Pd}_{6} \mathrm{CoCu} / \mathrm{C}$ nanoparticles since the equilibrium electrode potential of the $\mathrm{AuCl}_{4}^{-} / \mathrm{Au}$ couple $(0.93 \mathrm{~V}$ versus standard hydrogen electrode (SHE)) is more positive than those of the $\mathrm{Cu}^{2}+\mathrm{Cu}(0.34 \mathrm{~V}$ versus SHE) and $\mathrm{PdCl}_{4}^{2-} / \mathrm{Pd}(0.591 \mathrm{~V}$ versus SHE $)$ couples. The stability of $\mathrm{Pd}_{6} \mathrm{CoCu} / \mathrm{C}$ nanoparticles for ORR could be enhanced after $\mathrm{Au}$ replacement. The deposition procedure is similar to the one that we have previously reported ${ }^{14,30}$. XPS spectra clearly show $\mathrm{Au}_{4 \mathrm{f}}$ peaks (inset in Supplementary Fig. 4), indicating that Au has successfully replaced atoms on/in the $\mathrm{Pd}_{6} \mathrm{CoCu} / \mathrm{C}$ nanoparticle. Moreover, there is no evidence of a phase transformation after $\mathrm{Au}$ has been deposited as shown by X-ray diffraction measurements (Supplementary Fig. 5).

Figure 3a shows energy-dispersive $\mathrm{X}$-ray spectroscopic analysis of $\mathrm{Au}-\mathrm{Pd}_{6} \mathrm{CoCu} / \mathrm{C}$ nanoparticles in an aberration-corrected STEM. A line-profile was acquired on a single particle to reveal the elemental distribution of $\mathrm{Pd}, \mathrm{Co}, \mathrm{Cu}$ and Au using a $200 \mathrm{keV}$ aberration-corrected STEM (Fig. 3b). Interestingly and surprisingly, Au showed the same distribution profile as Pd, suggesting that $\mathrm{Au}$ penetrates through the entire particle as illustrated in Fig. 1. To demonstrate the elemental distribution of Au without ambiguity, we performed a two-dimensional (2D) mapping of the particle. The Au map shows the same spatial distribution as $\mathrm{Pd}$, again strongly supporting our assertion that $\mathrm{Au}$ atoms are uniformly incorporated into the nanoparticle (Fig. 3c).

The incorporation of $\mathrm{Au}$ was further examined by X-ray absorption spectroscopy (XAS). The Au-L3 X-ray absorption near-edge structure was used to discriminate between highly oxidized and reduced forms of the metal. Figure 4a compares a $\mathrm{Au}$ film and $\mathrm{Au}-\mathrm{Pd}_{6} \mathrm{CoCu} / \mathrm{C}$ nanoparticles. It can be clearly seen that both samples exhibit the characteristic three-peak pattern following the edge jump ${ }^{37}$, indicating that the gold in the $\mathrm{Au}-\mathrm{PdCuCo}$ sample is reduced (metallic). The 'whiteline' intensity of $\mathrm{Au}$, which is closely related to the d-band population, was slightly lower in $\mathrm{Au}-\mathrm{Pd}_{6} \mathrm{CoCu} / \mathrm{C}$ than that in the Au film, and the edge position was shifted to slightly higher energy. Most importantly, the small but significant decrease in intensity of the whiteline demonstrates a partial charge transfer from $\mathrm{Pd}$ to $\mathrm{Au}$ as observed and described in detail for $\mathrm{Au}-\mathrm{Pd}$ alloys in previous studies ${ }^{38-40}$.

The Fourier transform of the extended X-ray absorption fine structure of the $\mathrm{Au}$ film and $\mathrm{Au}-\mathrm{Pd}_{6} \mathrm{CoCu} / \mathrm{C}$ nanoparticles, measured at the Au-L3 edge, are shown in Fig. $4 \mathrm{~b}$. The two peaks in the spectra indicate that gold has two different near neighbours. We ascribe the decrease in magnitude of the firstshell peak in $\mathrm{Au}-\mathrm{Pd}_{6} \mathrm{CoCu} / \mathrm{C}$ relative to the gold foil to a lower coordination number of $\mathrm{Au}$ in the nanoparticle, which is 

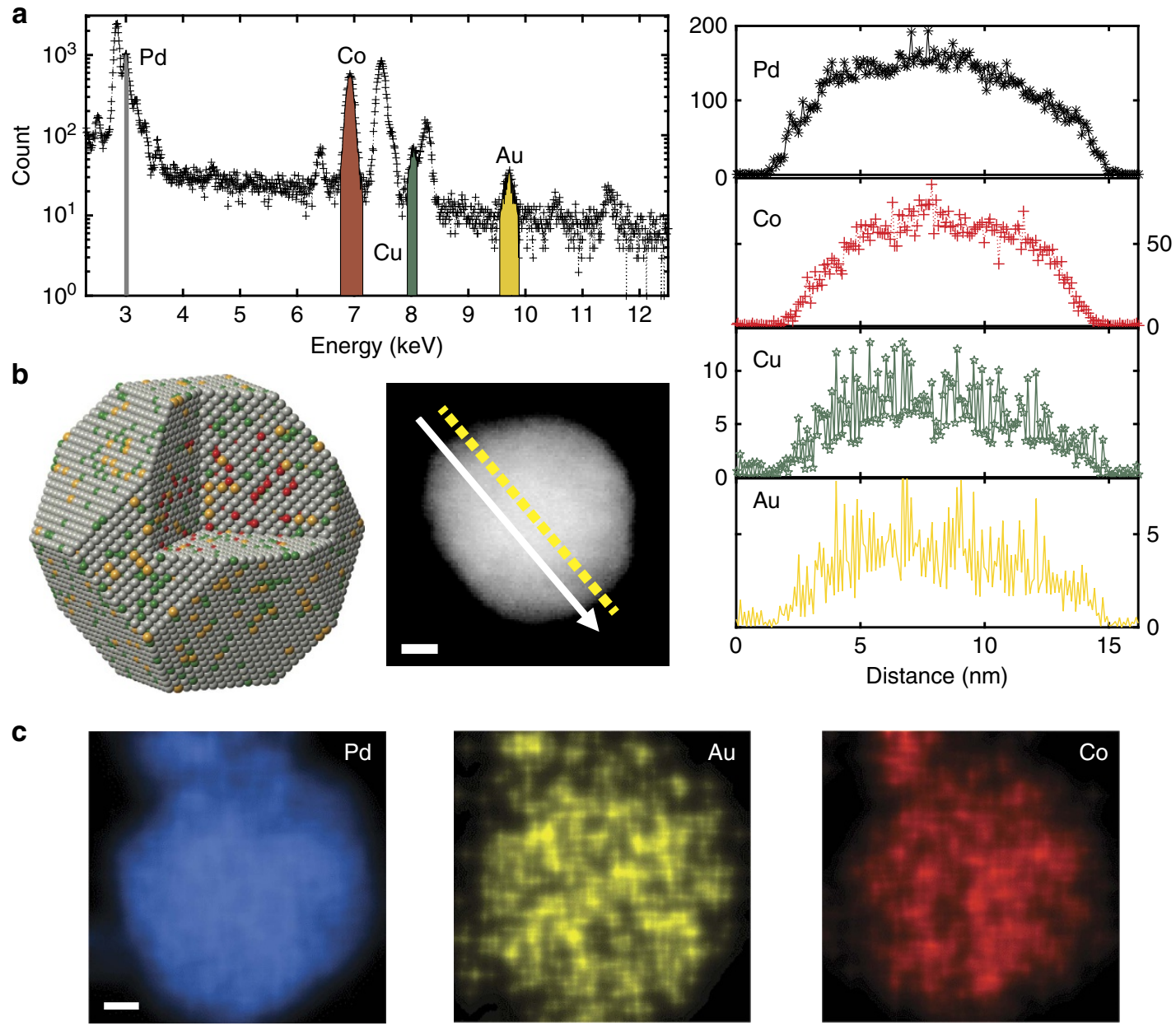

Figure 3 | Composition analysis of a $\mathbf{A u}-\mathbf{P d}_{6} \mathbf{C o C u} / \mathbf{C}$ nanoparticle. (a) Energy-dispersive $\mathrm{X}$-ray spectroscopic (EDX) analysis of $\mathrm{Au}-\mathrm{Pd}{ }_{6} \mathrm{CoCu} / \mathrm{C}$ nanoparticles. (b) Elemental distribution of $\mathrm{Pd}, \mathrm{Co}, \mathrm{Cu}$ and $\mathrm{Au}$ in a single $\mathrm{Au}-\mathrm{Pd}_{6} \mathrm{CoCu} / \mathrm{C}$ nanoparticle extracted from an aberration-corrected STEM-EDX line profile. Scale bar, $2 \mathrm{~nm}$. (c), Aberration-corrected STEM-EDX 2D elemental maps of Pd, Co and Au. Scale bar, $5 \mathrm{~nm}$.

a

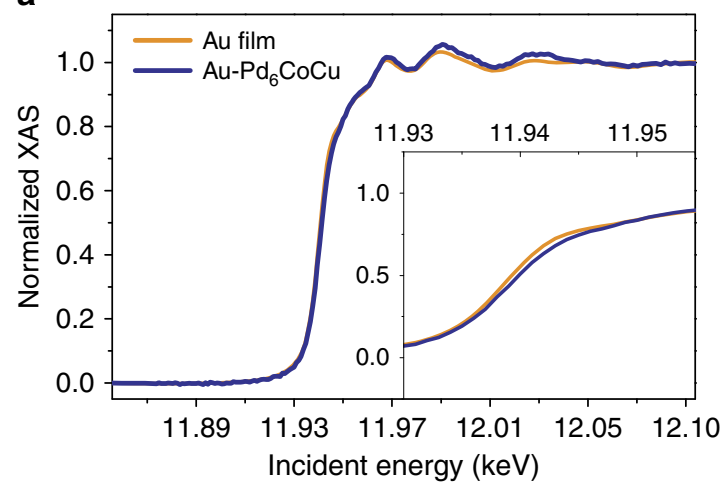

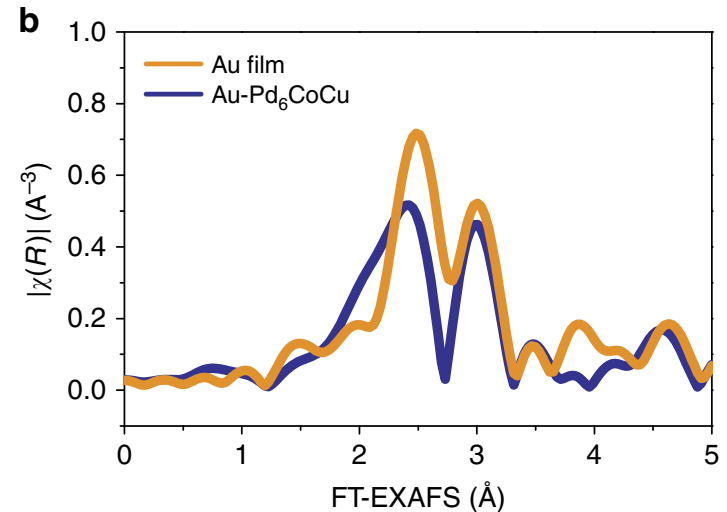

Figure 4 | X-ray absorption analysis. (a) XANES and (b) FT-EXAFS spectra of Au-L3 edge in a Au film and a Au-Pd 6 CoCu/C nanoparticle. EXAFS, extended X-ray absorption fine structure; XANES, X-ray absorption near-edge structure.

consistent with a previous XAS study of Pd-Au alloys by Sham ${ }^{38}$ and a consequence, at least in part, of the phase shifts of high- $Z$ absorbers and scatterers. In a word, the XAS study demonstrates that at the bulk ensemble level, $\mathrm{Au}$ has been uniformly incorporated in the $\mathrm{Pd}-\mathrm{Co}-\mathrm{Cu}$ lattice, rather than forming a $\mathrm{Au}$ shell or Au clusters.

The observation that $\mathrm{Au}$ can spontaneously penetrate the $\mathrm{Pd}-\mathrm{Co}-\mathrm{Cu}$ lattice to reach the interior of the particle might be related to the fact that the as-prepared $\mathrm{Pd}_{6} \mathrm{CoCu} / \mathrm{C}$ nanoparticles were $\mathrm{Pd}$ and $\mathrm{Cu}$ rich on the surface (Fig. 2c). The equilibrium electrode potential of the $\mathrm{Cu}^{2}+/ \mathrm{Cu}$ couple is lower than that of the $\mathrm{PdCl}_{4}^{2-} / \mathrm{Pd}$ couple. Therefore, it is likely that $\mathrm{Au}$ displaces $\mathrm{Cu}$ first, leaving the $\mathrm{Pd}$ atoms untouched. In addition, $\mathrm{Au}$ and $\mathrm{Pd}$ are intermixable at all proportions. Therefore, thermodynamically, it is favourable for Au to uniformly mix with Pd. This is in contrast to the previously investigated Pt- $\mathrm{Pd}_{3} \mathrm{Co}$ system ${ }^{14,30}$, where Pt can 
a

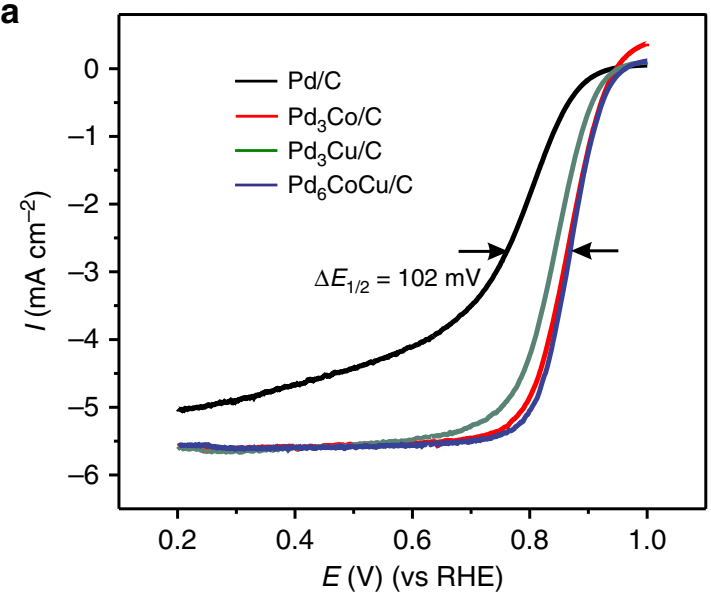

C

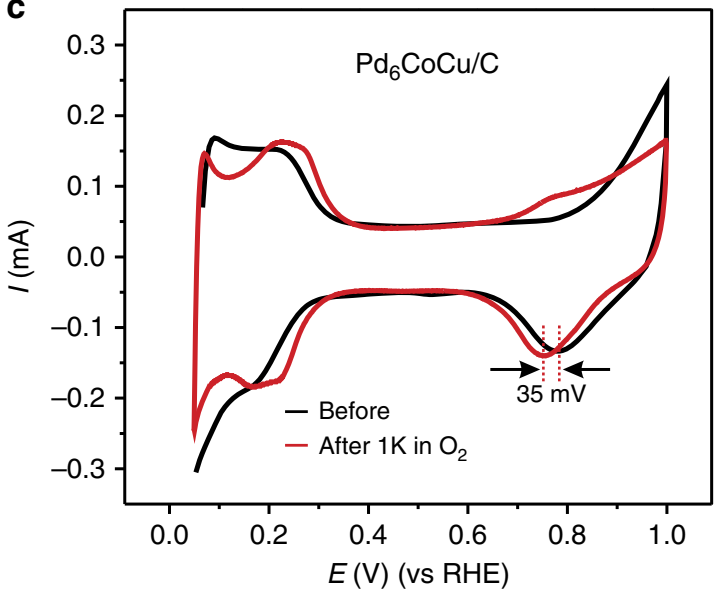

b

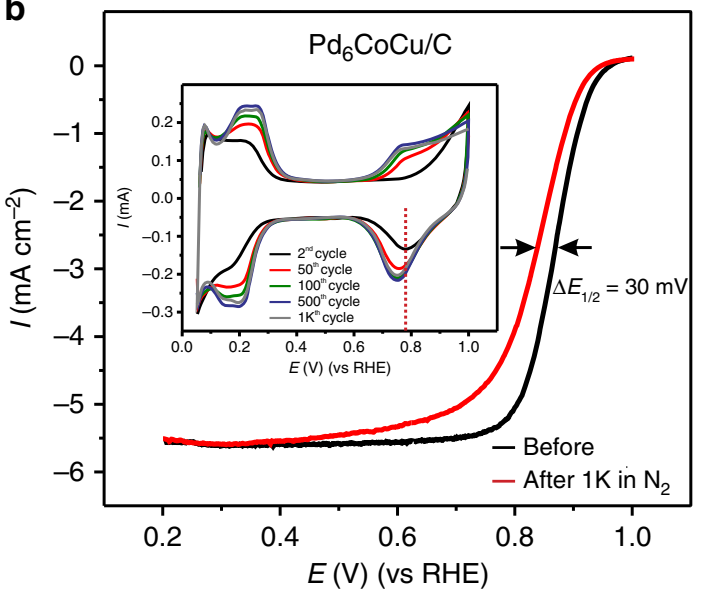

d

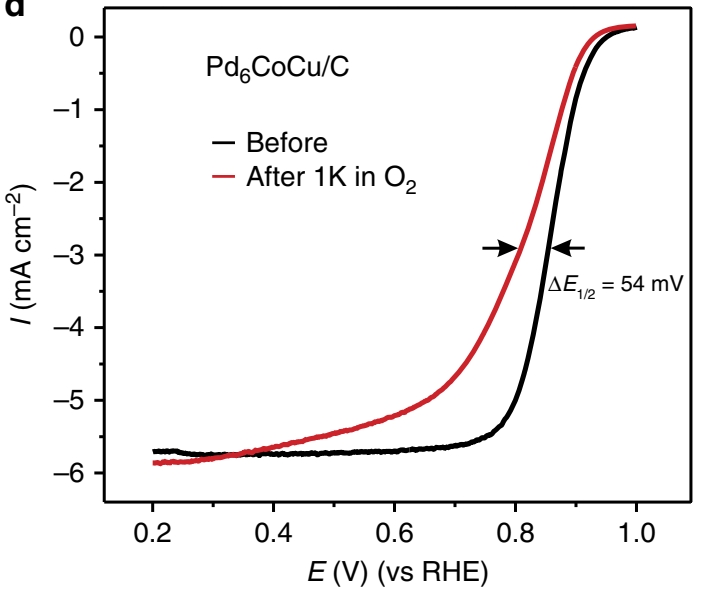

Figure 5 | Electrocatalytic activity for ORR. (a) Comparison of ORR polarization curves for $\mathrm{Pd} / \mathrm{C}, \mathrm{Pd}_{3} \mathrm{Co} / \mathrm{C}, \mathrm{Pd}{ }_{3} \mathrm{Cu} / \mathrm{C}$ and $\mathrm{Pd}{ }_{6} \mathrm{CoCu} / \mathrm{C}$ in $\mathrm{O}_{2}-\mathrm{saturated}$ $0.1 \mathrm{M} \mathrm{HClO}_{4}$ at room temperature; rotation rate, 1,600 r.p.m.; and sweep rate, $5 \mathrm{mVs}^{-1}$. (b) ORR polarization curves for $\mathrm{Pd}_{6} \mathrm{CoCu} / \mathrm{C}$ before and after 1,000 potential cycles in $\mathrm{N}_{2}$-saturated $0.1 \mathrm{M} \mathrm{HClO}_{4}$, rotation rate, 1,600 r.p.m. and sweep rate, $5 \mathrm{mVs}^{-1}$. The inset in $\mathbf{b}$ shows the changes in the $\mathrm{CV}$ profiles after different numbers of cycles at a sweep rate of $50 \mathrm{mVs}^{-1}$. (c) $\mathrm{CV}$ changes in the voltammetric profile for $\mathrm{Pd}_{6} \mathrm{CoCu} / \mathrm{C}$ before and after 1,000 potential cycles in $\mathrm{O}_{2}$-saturated $0.1 \mathrm{M} \mathrm{HClO}_{4}$ between 0.6 and $1.0 \mathrm{~V}$ at a sweep rate of $50 \mathrm{mV} \mathrm{s}^{-1}$. (d) ORR polarization curves for $\mathrm{Pd}_{6} \mathrm{CoCu} / \mathrm{C}$ before and after 1,000 potential cycles in $\mathrm{O}_{2}$-saturated $0.1 \mathrm{M} \mathrm{HClO}_{4}$, rotation rate, 1,600 r.p.m.; sweep rate, $5 \mathrm{mVs}^{-1}$.

only displace atoms on the surface of the nanoparticles and form a Pt-rich shell. The phase diagram shows that, in this case, $\mathrm{Pt}$ and $\mathrm{Pd}$ are not miscible in all proportions. With regards to the Pt-displacement experiment, we speculate that the intersolubility of $\mathrm{Au}$ and $\mathrm{Pd}$ might be one of the driving forces for $\mathrm{Au}$ to penetrate the $\mathrm{Pd}-\mathrm{Co}-\mathrm{Cu}$ bulk lattice and thus the entire nanoparticle.

Electrochemical and fuel-cell testing. The ORR activities of the electrocatalysts were evaluated in an $\mathrm{O}_{2}$-saturated $0.1 \mathrm{M} \mathrm{HClO}_{4}$ solution by loading the materials (with the same Pd mass loading) onto a glassy carbon rotating disk electrode with experiments performed at a rotation rate of 1,600 r.p.m. and a sweep rate of $5 \mathrm{mV} \mathrm{s}^{-1}$ at room temperature. All electrodes were pretreated by cycling the potential between +0.05 and $+1.00 \mathrm{~V}$ at a sweep rate of $50 \mathrm{mV} \mathrm{s}^{-1}$, for 50 cycles, before the ORR activity test. Polarization curves for the ORR of the different catalysts are shown in Fig. 5a. The ORR kinetics was markedly accelerated on the tri-metallic $\mathrm{Pd}_{6} \mathrm{CoCu} / \mathrm{C}$ alloy nanoparticles, and the half-wave potential $\left(E_{1 / 2}\right)$ was significantly positively shifted, relative to $\mathrm{Pd} / \mathrm{C}$ and $\mathrm{Pd}_{3} \mathrm{Cu} / \mathrm{C}$ nanoparticles, indicating a significant increase in the ORR activity. It can also be seen in Fig. 5a that the
$\mathrm{Pd}_{6} \mathrm{CoCu} / \mathrm{C}$ nanoparticles exhibit a slightly higher ORR activity than the $\mathrm{Pd}_{3} \mathrm{Co} / \mathrm{C}$ nanoparticles. This may be due to the smaller particle size and slightly different lattice parameter (Supplementary Table 1).

The durability of the $\mathrm{Pd}_{6} \mathrm{CoCu} / \mathrm{C}$ nanoparticles was evaluated by potential cycling between +0.05 and $+1.0 \mathrm{~V}$ at a scan rate of $50 \mathrm{mV} \mathrm{s}^{-1}$ for 1,000 cycles in $\mathrm{N}_{2}$-saturated $0.1 \mathrm{M} \mathrm{HClO}_{4}$ solution followed by an assessment of the ORR activity. As shown in Fig. 5b, after 1,000 potential cycles, the $\mathrm{Pd}_{6} \mathrm{CoCu} / \mathrm{C}$ catalyst showed a degradation of around $30 \mathrm{mV}$ in its half-wave potential for the ORR. The CVs after different numbers of cycles are presented in the inset to Fig. 5b. Durability tests were also conducted in $\mathrm{O}_{2}$-saturated $0.1 \mathrm{M}$ $\mathrm{HClO}_{4}$ solution between +0.6 and $+1.0 \mathrm{~V}$ at a scan rate of $50 \mathrm{mV} \mathrm{s}^{-1}$ for 1,000 potential cycles. It can be seen from changes in the CVs (Fig. 5c) that the hydrogen adsorption/ desorption peaks shifted to positive potentials, while the peak potential for the reduction of the Pd oxides shifted negatively by $\sim 35 \mathrm{mV}$. The ORR durability, presented in Fig. 5d, shows a significant negative shift in the half-wave potential of about $54 \mathrm{mV}$ after 1,000 potential cycles, indicating that the decay in the catalytic activity of $\mathrm{Pd}_{6} \mathrm{CoCu} / \mathrm{C}$ was accelerated when cycling in the presence of oxygen. 
a

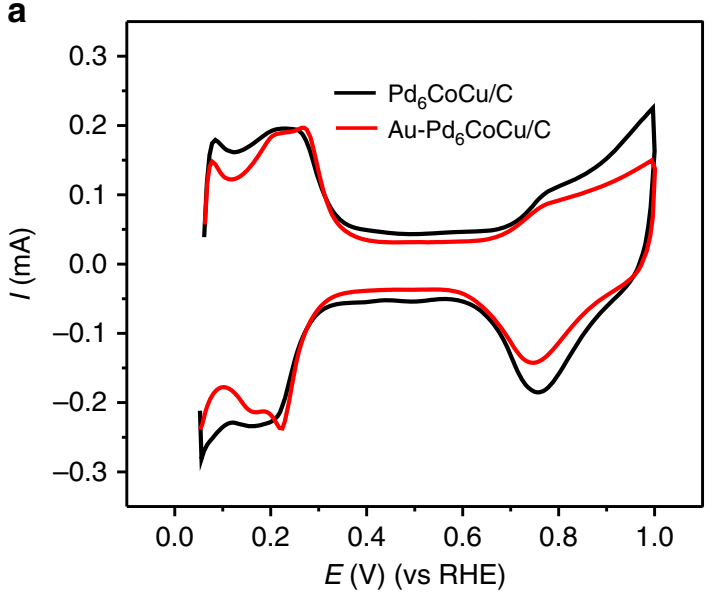

C

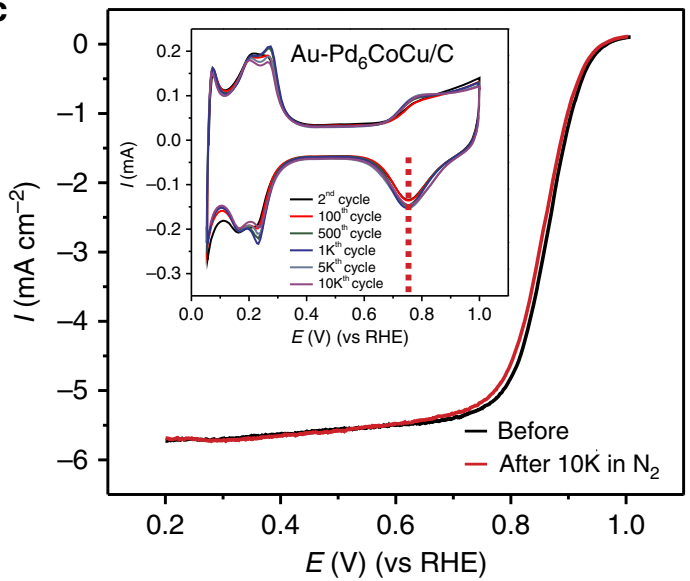

b

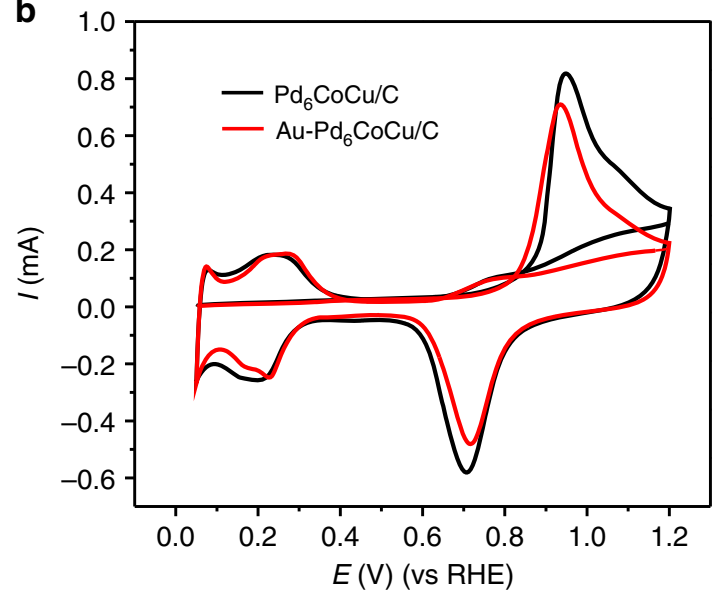

d

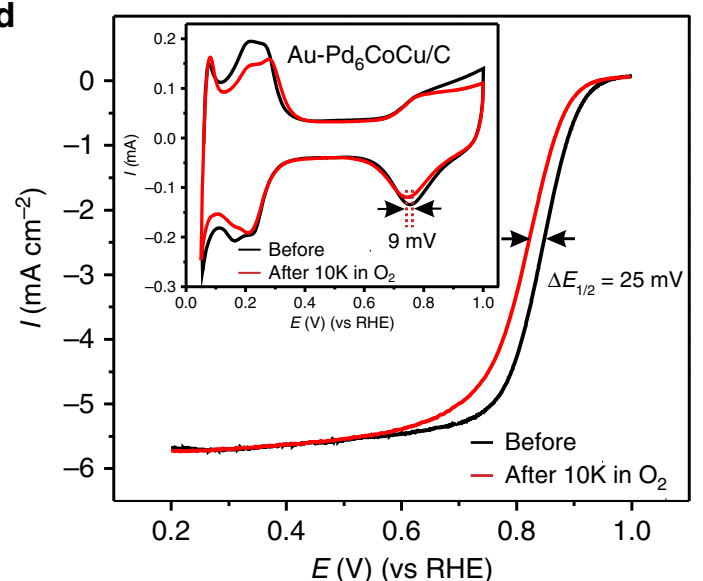

Figure 6 | Electrochemical measurements. (a) $\mathrm{CVs}$ and (b) $\mathrm{CO}$ stripping of $\mathrm{Pd}_{6} \mathrm{CoCu} / \mathrm{C}$ nanoparticles with and without $\mathrm{Au}$ decoration in $0.1 \mathrm{M} \mathrm{HClO}{ }_{4}$ purged with $\mathrm{N}_{2}$, sweep rate, $50 \mathrm{mVs}^{-1}$. (c) ORR polarization curves of $\mathrm{Au}-\mathrm{Pd}_{6} \mathrm{CoCu} / \mathrm{C}$ nanoparticles before and after cycling in $\mathrm{N}_{2}$-saturated $0.1 \mathrm{M} \mathrm{HClO}$; rotation rate, 1,600 r.p.m.; and sweep rate, $5 \mathrm{mVs}^{-1}$. The inset in c shows $\mathrm{CVs}$ of the $\mathrm{Au}-\mathrm{Pd}_{6} \mathrm{CoCu} / \mathrm{C}$ nanoparticles after different numbers of potential cycles between 0.05 and $1.0 \mathrm{~V}$ in $\mathrm{N}_{2}$-saturated $0.1 \mathrm{M} \mathrm{HClO}_{4}$ and sweep rate, $50 \mathrm{mVs}^{-1}$. (d) ORR polarization curves of $\mathrm{Au}-\mathrm{Pd}_{6} \mathrm{CoCu} / \mathrm{C}$ nanoparticles before and after cycling in $\mathrm{O}_{2}$-saturated $0.1 \mathrm{M} \mathrm{HClO}_{4}$ between 0.6 and $1.0 \mathrm{~V}$; rotation rate, 1,600 r.p.m. and sweep rate, $5 \mathrm{mVs}{ }^{-1}$. The inset in $\mathbf{d}$ shows changes in the voltammetric profile for $\mathrm{Au}-\mathrm{Pd}_{6} \mathrm{CoCu} / \mathrm{C}$ before and after 10,000 potential cycles between 0.6 and $1.0 \mathrm{~V}$ in $\mathrm{O}_{2}$-saturated $0.1 \mathrm{M} \mathrm{HClO}$, sweep rate, $50 \mathrm{mVs}^{-1}$.

The decay in electrocatalytic activity for the ORR on $\mathrm{Pd}_{6} \mathrm{CoCu} /$ $\mathrm{C}$ electrode, after continuous cycling, most likely arises from surface changes during cycling. Since the initial surface of the $\mathrm{Pd}_{6} \mathrm{CoCu} / \mathrm{C}$ nanoparticles is a Pd-Cu-rich alloy (Fig. 2b,c; $\mathrm{Pd}$ and $\mathrm{Cu}$ are evenly distributed on the surface), the $\mathrm{Cu}$ dissolves during potential cycling, causing the lattice strained Pd surface to expand with $\mathrm{Cu}$ leaching out of the nanoparticle surface. The surface composition changes can be seen clearly from the CVs of the $\mathrm{Pd}_{6} \mathrm{CoCu} / \mathrm{C}$ nanoparticle after different cycles (inset of Fig. $5 \mathrm{~b}, \mathrm{c}$ ). The onset of Pd oxide formation, and the Pd oxides reduction peaks shift towards negative potentials with cycling. The readily formed Pd oxides inhibit the $\mathrm{OH}_{\mathrm{ad}}$ species on the $\mathrm{Pd}_{6} \mathrm{CoCu} / \mathrm{C}$ electrode surface and block the active sites for $\mathrm{O}_{2}$ adsorption, causing the decay in the ORR activity.

After replacement with $\mathrm{Au}$ the $\mathrm{CV}$ of the $\mathrm{Pd}_{6} \mathrm{CoCu} / \mathrm{C}$ nanoparticle changed significantly. As shown in Fig. 6a, the total surface area decreased (see also the CO stripping in Fig. 6b) and the double layer current also decreased. In the hydrogen region, the Au-decorated $\mathrm{Pd}_{6} \mathrm{CoCu}$ nanoparticles exhibited, two well-defined hydrogen adsorption/desorption peaks compared with one broad hydrogen peak for $\mathrm{Pd}_{6} \mathrm{CoCu} / \mathrm{C}$ nanoparticles, from +0.1 to $+0.3 \mathrm{~V}$. In addition, the Pd oxides reduction peak shifted slightly negative after Au decoration. Because the Au atom is larger than Pd, the lattice parameter of Pd on the top layer of the nanoparticle will expand after $\mathrm{Au}$ incorporation. The expanded lattice will modify the oxygen adsorption energy of the nanocatalyst, causing the negative shift of the oxides reduction peak. The same phenomenon can also be seen in the CO-stripping voltammetry (Fig. 6b), which shows that the onset and peak potential for $\mathrm{CO}$ oxidation, shifted slightly negative after Au-decoration of the $\mathrm{Pd}_{6} \mathrm{CoCu} / \mathrm{C}$ nanoparticles.

The stabilizing effect of $\mathrm{Au}$ on the $\mathrm{Pd}_{6} \mathrm{CoCu} / \mathrm{C}$ nanoparticles was evaluated by cycling the electrode in both $\mathrm{N}_{2^{-}}$and $\mathrm{O}_{2}$-saturated $0.1 \mathrm{M} \mathrm{HClO}_{4}$ solutions, respectively. As shown in the inset of Fig. $6 \mathrm{c}, \mathrm{d}$, the $\mathrm{CVs}$ of the $\mathrm{Au}-\mathrm{Pd}_{6} \mathrm{CoCu} / \mathrm{C}$ nanoparticles in an $\mathrm{N}_{2}$ atmosphere changed slightly with increasing number of potential cycles. Moreover, unlike the $\mathrm{Pd}_{6} \mathrm{CoCu} / \mathrm{C}$ catalysts, the peak position of the $\mathrm{Pd}$ oxides reduction remained unchanged in the $\mathrm{N}_{2}$ atmosphere, although it shifted negatively by about $9 \mathrm{mV}$ in the $\mathrm{O}_{2}$ atmosphere after 10,000 potential cycles, indicating that the $\mathrm{Pd}_{6} \mathrm{CoCu} / \mathrm{C}$ catalyst was stabilized by the Au decoration. Besides, the morphology of the $\mathrm{Au}-\mathrm{Au}-\mathrm{Pd}_{6} \mathrm{CoCu} / \mathrm{C}$ nanoparticles remained almost spherical after potential cycles, although the average size was slightly increased (Supplementary Fig. 6). The catalytic activity for the ORR of the $\mathrm{Au}-\mathrm{Pd}_{6} \mathrm{CoCu} / \mathrm{C}$ catalyst exhibited a slight 

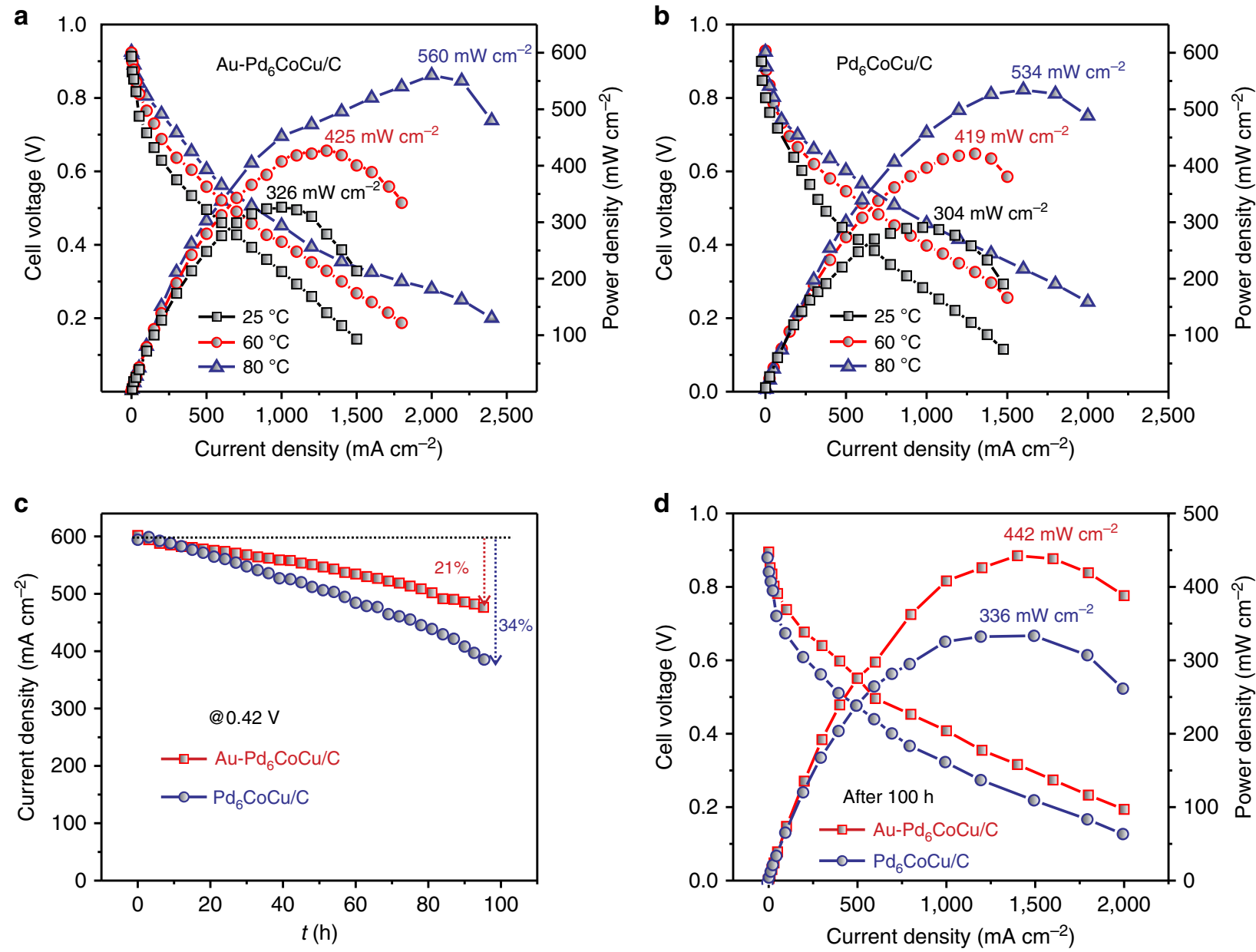

Figure 7 | Single-cell performance. (a) Polarization and power-density curves for PEMFCs, using a Au-Pd 6 CoCu/C cathode catalyst at 25,60 and $80{ }^{\circ} \mathrm{C}$. (b) Polarization and power-density curves for PEMFCs using a $\mathrm{Pd}_{6} \mathrm{CoCu} / \mathrm{C}$ cathode catalyst at 25,60 and $80^{\circ} \mathrm{C}$. (c) Stability evaluation of $\mathrm{Au}-\mathrm{Pd}{ }_{6} \mathrm{CoCu} / \mathrm{C}$ and $\mathrm{Pd}_{6} \mathrm{CoCu} / \mathrm{C}$ cathodes on polarizing the cell at $0.42 \mathrm{~V}$ for $100 \mathrm{~h}$ in a single cell at $80^{\circ} \mathrm{C}$. (d) Comparison of the polarization and power densities for PEMFCs using a Au- $\mathrm{Pd}_{6} \mathrm{CoCu} / \mathrm{C}$ and $\mathrm{Pd}_{6} \mathrm{CoCu} / \mathrm{C}$ cathode catalyst after life test at $80^{\circ} \mathrm{C}$. Pt/C (Alfa Aesar, 40 wt $\%$ ) was used as the anode catalyst, and the metal loading was $0.5 \mathrm{mg} \mathrm{cm}^{-2}$ in both the anode and cathode. The current density values given are with respect to geometric electrode area.

degradation in the half-wave potential after 10,000 cycles in $\mathrm{N}_{2-}$ saturated $0.1 \mathrm{M} \mathrm{HClO}_{4}$ solution between +0.05 and $+1.0 \mathrm{~V}$ (Fig. 6c). In contrast, the $\mathrm{Pd}_{6} \mathrm{CoCu} / \mathrm{C}$ catalyst exhibited a shift of $\sim 30 \mathrm{mV}$ (Fig. 5b). After testing the electrode for 10,000 potential cycles in $\mathrm{O}_{2}$-saturated $0.1 \mathrm{M} \mathrm{HClO}_{4}$ solution between +0.6 and $+1.0 \mathrm{~V}$ at a scan rate of $50 \mathrm{mV} \mathrm{s}^{-1}$ (Fig. 6d), the electrochemical surface area decreased by only $13.8 \%$ when compared with the initial value. The half-wave potential shifted negatively by about $25 \mathrm{mV}$, a value that is much lower than that of the $\mathrm{Pd}_{6} \mathrm{CoCu} / \mathrm{C}$ electrode, after only 1,000 cycles $(54 \mathrm{mV})$. The enhancement in the stability likely derives from the partial charge donation of Pd to $\mathrm{Au}$ (Fig. 4a) and slight expansion of the Pd lattice (Fig. 6a; Supplementary Table 1), thus enhancing the durability of $\mathrm{Pd}$ during cycling.

The stability of the $\mathrm{Au}-\mathrm{Pd}_{6} \mathrm{CoCu} / \mathrm{C}$ cathode was further evaluated and compared with $\mathrm{Pd}_{6} \mathrm{CoCu} / \mathrm{C}$ cathode in a single-cell PEMFC with commercial $\mathrm{Pt} / \mathrm{C}$ as the anode (Fig. 7). Figure 7a shows the fuel-cell performance using $\mathrm{Au}-\mathrm{Pd}_{6} \mathrm{CoCu} / \mathrm{C}$ as the cathode electrocatalyst at different temperatures. It was observed that the fuel-cell performance was enhanced with increasing operating temperature. The maximum power density at $25^{\circ} \mathrm{C}$ was $326 \mathrm{~mW} \mathrm{~cm}^{-2}$. It increased to 425 and $560 \mathrm{~mW} \mathrm{~cm}^{-2}$ at $60^{\circ} \mathrm{C}$ and $80^{\circ} \mathrm{C}$, which is almost $30 \%$ and $72 \%$ higher than the starting value, respectively. This behaviour suggests that the oxygen reduction kinetics at the $\mathrm{Au}-\mathrm{Pd}_{6} \mathrm{CoCu} / \mathrm{C}$ nanoparticles were enhanced by increasing the temperature. The fuel-cell performance using $\mathrm{Pd}_{6} \mathrm{CoCu} / \mathrm{C}$ as the cathode electrocatalyst at different temperatures exhibited similar behaviour as $\mathrm{Au}-\mathrm{Pd}_{6} \mathrm{CoCu} / \mathrm{C}$ (Fig. 7b). The long-term durability of the catalysts was assessed by recording the current density with time at a constant cell voltage of $0.42 \mathrm{~V}$ at $80^{\circ} \mathrm{C}$ for $100 \mathrm{~h}$ (Fig. 7c) and the polarization and power-density curves before and after polarizing the fuel cell (Fig. $7 \mathrm{~d}$ ). The $\mathrm{Au}-\mathrm{Pd}_{6} \mathrm{CoCu} / \mathrm{C}$ cathode exhibited higher durability. The losses in the current density and in maximum power density were both about $21 \%$. Compared with the losses of 34 and $37 \%$ in the current density and the maximum power density observed from the $\mathrm{Pd}_{6} \mathrm{CoCu} / \mathrm{C}$ cathode, it further demonstrates that $\mathrm{Au}$ decoration enhanced the durability of $\mathrm{Pd}_{6} \mathrm{CoCu} / \mathrm{C}$ cathode electrocatalysts.

\section{Discussion}

The use of gold to stabilize fuel-cell nanocatalyts for the ORR has become an increasingly attractive strategy. However, developing a synthetic procedure that can lower $\mathrm{Pt}$ and $\mathrm{Au}$ usage, while preserving scalability for industrial production, has remained challenging and elusive. The method that we have developed, and which we present here, is extremely effective and scalable and 
addresses the above-mentioned challenges. Compared with methods pioneered by the Adzic group, which are only applicable to laboratory scale experiments, our strategy eliminates the need to carry out lengthy synthesis steps ${ }^{36}$ and $\mathrm{Cu}$ under-potential deposition $^{34}$. In addition, we have demonstrated that only trace amounts of gold ( $\mathrm{Au}: \mathrm{Pd}=1: 100)$ are needed to stablize the Pd-based alloy particles. This is almost a two-orders of magnitude lower loading of gold, compared with results reported in previous $\mathrm{Au}-\mathrm{Pd}$ studies ${ }^{29,36}$. Moreover, according to the previous study ${ }^{34}$, we expected that the $\mathrm{Pd}_{6} \mathrm{CoCu}$ particles would have been decorated with a $\mathrm{Au}$ overlayer or Au clusters. Contrary to that expectation, in the present work we found that gold atoms actually penetrate the $\mathrm{Pd}-\mathrm{Co}-\mathrm{Cu}$ lattice and uniformly distribute within the particles without disrupting the host particle structure. Therefore, our strategy offers not only technological advances, but also undiscovered new structures and synthesis routes.

In summary, a ternary $\mathrm{Pd}_{6} \mathrm{CoCu}$ nanoparticle catalyst with ultralow amounts of $\mathrm{Au}$ decoration $\left(\mathrm{Au}-\mathrm{Pd}_{6} \mathrm{CoCu} / \mathrm{C}\right)$ has been successfully prepared by a simple spontaneous replacement method. Contrary to all previous examples, the $\mathrm{Au}$ is homogeneously distributed throughout the nanoparticles (over 10,000 cycles). The $\mathrm{Au}-\mathrm{Pd}_{6} \mathrm{CoCu} / \mathrm{C}$ catalysts exhibited excellent stability for the ORR under-potential cycling both in $\mathrm{N}_{2^{-}}$and $\mathrm{O}_{2^{-}}$ saturated $0.1 \mathrm{M} \mathrm{HClO}_{4}$ solution. The single fuel-cell test indicates that the durability of $\mathrm{Au}-\mathrm{Pd}_{6} \mathrm{CoCu} / \mathrm{C}$ significantly enhances the 100 -h life test compared with $\mathrm{Pd}_{6} \mathrm{CoCu} / \mathrm{C}$. The high durability of the electrocatalyst for the ORR can be ascribed to the homogeneous distribution of gold and the charge transfer of $\mathrm{Pd}$ to Au, causing a reduction of the $d$-electron occupation of $\mathrm{Pd}$ with a slightly expanded lattice, which enhances the corrosion resistance of $\mathrm{Pd}$. This study provides a new strategy for optimizing the stability of fuel-cell catalysts.

\section{Methods \\ Material synthesis. Carbon supported $\mathrm{Pd}_{3} \mathrm{Co}, \mathrm{Pd}_{3} \mathrm{Cu}$ and $\mathrm{Pd}_{6} \mathrm{CoCu}$ nanoparticles with $20 \mathrm{wt} \%$ of $\mathrm{Pd}$ were prepared using an impregnation method. In a typical synthesis for $\mathrm{Pd}_{6} \mathrm{CoCu} / \mathrm{C}, 67 \mathrm{mg}$ of $\mathrm{PdCl}_{2}, 14.9 \mathrm{mg}$ of $\mathrm{CoCl}_{2} \cdot 6 \mathrm{H}_{2} \mathrm{O}$ and $10.7 \mathrm{mg}$ of $\mathrm{CuCl}_{2} \cdot 2 \mathrm{H}_{2} \mathrm{O}$ were first dissolved in deionized water, and $152 \mathrm{mg}$ of preheated Vulcan XC-72 carbon support were dispersed in the solution. After ultrasonic blending for $30 \mathrm{~min}$, the suspension was heated under magnetic stirring to allow the solvent to evaporate and to form a smooth, thick slurry. The slurry was dried in an oven at $60^{\circ} \mathrm{C}$ overnight and grounded in an agate mortar, the resulting dark and free- flowing powder was then reduced in a tube furnace at $150{ }^{\circ} \mathrm{C}$ under flowing $\mathrm{H}_{2} / \mathrm{N}_{2}$ for $2 \mathrm{~h}$. $\mathrm{Pd}_{3} \mathrm{Cu} / \mathrm{C}$ and $\mathrm{Pd}_{3} \mathrm{Co} / \mathrm{C}$ were prepared in the same procedure for comparison. The as-prepared $\mathrm{Pd}_{3} \mathrm{Cu} / \mathrm{C}, \mathrm{Pd}_{3} \mathrm{Co} / \mathrm{C}$ and $\mathrm{Pd}_{6} \mathrm{CoCu} / \mathrm{C}$ nanoparticles were heat-treated at $500^{\circ} \mathrm{C}$ under a flowing $\mathrm{H}_{2}$ atmosphere for $10 \mathrm{~h}$ to form a Pd-rich shell. \\ The Au-decorated $\mathrm{Pd}_{6} \mathrm{CoCu} / \mathrm{C}$ nanoparticles were prepared by a spontaneous displacement reaction. Fifty milligrams of the as-prepared carbon-supported $\mathrm{Pd}_{6} \mathrm{CoCu} / \mathrm{C}$ nanoparticles were suspended in $10 \mathrm{ml}$ of $0.1 \mathrm{mM} \mathrm{NaAuCl} \mathrm{m}_{4}$ solution. One monolayer of $\mathrm{Au}$ (calculated from stoichiometric ratios) was deposited on the $\mathrm{Pd}_{6} \mathrm{CoCu} / \mathrm{C}$ nanoparticles surface (the atomic ratio of $\mathrm{Pd}$ to $\mathrm{Au}$ is $\sim 100: 1$ ). After ultrasonic blending for $30 \mathrm{~min}$, the suspension was heated to $60^{\circ} \mathrm{C}$ under magnetic stirring and left to react for $5 \mathrm{~h}$. The sample was then centrifuged and washed using deionized water until the $\mathrm{pH}$ value was close to 7 , and finally dried in a vacuum oven overnight.}

Characterization. The catalysts were characterized by using an X'Pert PRO diffractometer, and diffraction patterns were collected at a scanning rate of $4^{\circ}$ per min. The STEM-EELS maps were acquired on a 5 th order aberration-corrected STEM (Nion UltraSTEM) operated at $100 \mathrm{kV}$, with a convergence angle $\alpha_{\max }=$ $\sim 30$ mrad. The STEM-EDX line profile was acquired on an aberration-corrected JEOL ARM200CF operated at $200 \mathrm{keV}$ with a Large Angle SDD-EDX detector, DrySD100GV. The effective detection area is $100 \mathrm{~mm}^{2}$. A nickel TEM grid was used to avoid background signals from $\mathrm{Cu}$. The 2D STEM-EDX map was acquired on an aberration-corrected dedicated STEM (Hitachi HD2700C) operated at $200 \mathrm{keV}$ with a Bruker SSD EDX detector. XPS data were obtained using an AXISULTRA DLD-600 W Instrument.

Electrochemical testing. Electrochemical experiments were carried out in $0.1 \mathrm{M}$ $\mathrm{HClO}_{4}$ at room temperature using an Autolab electrochemistry station. Working electrodes were prepared by applying a thin catalyst film onto a glassy carbon electrode (GC, $5 \mathrm{~mm}$ in diameter). The catalyst ink was prepared by mixing $5 \mathrm{mg}$ of the catalyst with $1 \mathrm{ml}$ of Nafion (0.05wt\% Nafion dissolved in ethanol) solution. The mixture was sonicated and about $5.0 \mu$ l were applied onto a glassy carbon disk. After solvent evaporation, a thin layer of the Nafion-catalyst-Vulcan ink remained on the GC surface to serve as the working electrode. The Pd loading on the rotating disk electrode was calculated as $25.5 \mu \mathrm{g}_{\mathrm{Pd}}$ per $\mathrm{cm}^{2}$. A Pt wire was used as the counter electrode and a reversible hydrogen electrode, in the same electrolyte as the electrochemical cell, was used as the reference electrode. All potentials are referred to the reversible hydrogen electrode. The ORR polarization curves were obtained by sweeping the potential from +0.20 to $+1.0 \mathrm{~V}$ at a scan rate of $5 \mathrm{mV} \mathrm{s}^{-1}$ and at a rotation rate of 1,600 r.p.m.

MEA preparation and electrochemical investigation in single cells. Membrane electrode assemblies (MEAs), with an active electrode area of $1 \mathrm{~cm}^{2}$, were prepared using the gas-diffusion electrode method. Pt/C (Alfa Aesar, $40 \mathrm{wt} \%$ ) was used as the anode and the as-prepared $\mathrm{Pd}_{6} \mathrm{CoCu} / \mathrm{C}$ and $\mathrm{Au}-\mathrm{Pd}_{6} \mathrm{CoCu} / \mathrm{C}$ nanoparticles were used as the cathode catalysts. The catalyst loading was $0.2 \mathrm{mg}_{\mathrm{Pt}}$ per $\mathrm{cm}^{2}$ on the anode and $0.25 \mathrm{mg}_{\mathrm{Pd}}$ per $\mathrm{cm}^{2}$ on the cathode. The anode and cathode gas-diffusion electrodes were placed on the two sides of a Nafion 211 membrane (DuPont), and then were hot-pressed with a pressure of $0.5 \mathrm{MPa}$ for $1 \mathrm{~min}$ at $140^{\circ} \mathrm{C}$ to form an MEA. The MEA was inserted into a single-cell module for testing. The single cell was activated at a cell temperature of $80^{\circ} \mathrm{C}$. Fully humidified $\mathrm{H}_{2}$ and $\mathrm{O}_{2}$ were supplied to the anode and the cathode with a flow rate of 300 and 500 s.c.c.m., respectively. During the activation process, the current density was held constant for $30 \mathrm{~min}$ every time it reached $0.5,1,1.5$ and $2 \mathrm{~A} \mathrm{~cm}^{-2}$. Polarization curves were recorded in a galvanostatic mode (without ohmic; iR-correction) with a hold time of $3 \mathrm{~min}$ per point. To study the temperature effects on the cell performance, polarization curves were recorded at $25,40,60$ and $80^{\circ} \mathrm{C}$. Durability tests were performed at a constant potential of $0.42 \mathrm{~V}$ for $100 \mathrm{~h}$ of polarization after conditioning as described above without interruption. The humidity and temperature were kept the same as during the polarization tests.

Data availability. The authors declare that all the data supporting the findings of this study are available within the article and its Supplementary Information files.

\section{References}

1. Strasser, P. et al. Lattice-strain control of the activity in dealloyed core-shell fuel cell catalysts. Nat. Chem. 2, 454-460 (2010).

2. Greeley, J. et al. Alloys of platinum and early transition metals as oxygen reduction electrocatalysts. Nat. Chem. 1, 552-556 (2009).

3. Cui, C. H. et al. Compositional segregation in shaped Pt alloy nanoparticles and their structural behaviour during electrocatalysis. Nat. Mater. 12, 765-771 (2013).

4. Stamenkovic, V. R. et al. Trends in electrocatalysis on extended and nanoscale Pt-bimetallic alloy surfaces. Nat. Mater. 6, 241-247 (2007).

5. Stamenkovic, V. R. et al. Improved oxygen reduction activity on $\mathrm{Pt} 3 \mathrm{Ni}(111)$ via increased surface site availability. Science 315, 493-497 (2007).

6. Golikand, A. N. et al. Electrocatalytic oxygen reduction on single-walled carbon nanotubes supported $\mathrm{Pt}$ alloys nanoparticles in acidic and alkaline conditions. J. Appl. Electrochem. 39, 1369-1377 (2009).

7. Jiang, L. et al. Oxygen reduction reaction on carbon supported $\mathrm{Pt}$ and $\mathrm{Pd}$ in alkaline solutions. J. Electrochem. Soc. 156, B370-B376 (2009).

8. Wang, D. L. et al. Structurally ordered intermetallic platinum-cobalt core-shell nanoparticles with enhanced activity and stability as oxygen reduction electrocatalysts. Nat. Mater. 12, 81-87 (2013).

9. Zhou, W., Wu, J. B. \& Yang, H. Highly uniform platinum icosahedra made by hot injection-assisted GRAILS method. Nano Lett. 13, 2870-2874 (2013).

10. $\mathrm{Yu}$, T. et al. Platinum concave nanocubes with high-index facets and their enhanced activity for oxygen reduction reaction. Angew. Chem. Int. Ed. Engl. 50, 2773-2777 (2011).

11. Wang, D. L. et al. Tuning oxygen reduction reaction activity via controllable dealloying: a model study of ordered $\mathrm{Cu}_{3} \mathrm{Pt} / \mathrm{C}$ intermetallic nanocatalysts. Nano Lett. 12, 5230-5238 (2012).

12. Oezaslan, M., Heggen, M. \& Strasser, P. Size-dependent morphology of dealloyed bimetallic catalysts: linking the nano to the macro scale. J. Am. Chem. Soc. 134, 514-524 (2012).

13. Chen, C. et al. Highly crystalline multimetallic nanoframes with threedimensional electrocatalytic surfaces. Science 343, 1339-1343 (2014).

14. Wang, D. et al. Pt-decorated PdCo@Pd/C Core-shell nanoparticles with enhanced stability and electrocatalytic activity for the oxygen reduction reaction. J. Am. Chem. Soc. 132, 17664-17666 (2010).

15. Zhou, W. P. et al. Improving electrocatalysts for $\mathrm{O}_{2}$ reduction by fine-tuning the Pt-support interaction: Pt monolayer on the surfaces of a $\mathrm{Pd}_{3} \mathrm{Fe}(111)$ singlecrystal alloy. J. Am. Chem. Soc. 131, 12755-12762 (2009).

16. Zhang, Y. W. et al. Manageable N-doped graphene for high performance oxygen reduction reaction. Sci. Rep. 3, 2771 (2013).

17. Yin, H. J. et al. Facile synthesis of surfactant-free Au cluster/graphene hybrids for high-performance oxygen reduction reaction. Acs Nano 6, 8288-8297 (2012). 
18. Shao, M. H. et al. Palladium monolayer and palladium alloy electrocatalysts for oxygen reduction. Langmuir 22, 10409-10415 (2006).

19. Zhang, R. Z. \& Chen, W. Non-precious Ir-V bimetallic nanoclusters assembled on reduced graphene nanosheets as catalysts for the oxygen reduction reaction. J. Mater. Chem. A 1, 11457-11464 (2013).

20. Li, Y. G. et al. An oxygen reduction electrocatalyst based on carbon nanotubegraphene complexes. Nat. Nanotechnol. 7, 394-400 (2012).

21. Liang, Y. Y. et al. $\mathrm{Co}_{3} \mathrm{O}_{4}$ nanocrystals on graphene as a synergistic catalyst for oxygen reduction reaction. Nat. Mater. 10, 780-786 (2011).

22. Bashyam, R. \& Zelenay, P. A class of non-precious metal composite catalysts for fuel cells. Nature 443, 63-66 (2006).

23. Cheng, F. Y. et al. Rapid room-temperature synthesis of nanocrystalline spinels as oxygen reduction and evolution electrocatalysts. Nat. Chem. 3, 79-84 (2011).

24. Gong, K. P. et al. Nitrogen-doped carbon nanotube arrays with high electrocatalytic activity for oxygen reduction. Science 323, 760-764 (2009).

25. Shao, M. H., Sasaki, K. \& Adzic, R. R. Pd-Fe nanoparticles as electrocatalysts for oxygen reduction. J. Am. Chem. Soc. 128, 3526-3527 (2006).

26. Li, B. \& Prakash, J. Oxygen reduction reaction on carbon supported Palladium-Nickel alloys in alkaline media. Electrochem. Commun. 11, 1162-1165 (2009).

27. Shao, M. et al. Pt mono layer on porous $\mathrm{Pd}-\mathrm{Cu}$ alloys as oxygen reduction electrocatalysts. J. Am. Chem. Soc. 132, 9253-9255 (2010).

28. Fernandez, J. L. et al. Pd-Ti and Pd-Co-Au electrocatalysts as a replacement for platinum for oxygen reduction in proton exchange membrane fuel cells. J. Am. Chem. Soc. 127, 13100-13101 (2005).

29. Sasaki, K. et al. Highly stable Pt monolayer on PdAu nanoparticle electrocatalysts for the oxygen reduction reaction. Nat. Commun. 3, 1115-1124 (2012).

30. Wang, D. L. et al. Facile synthesis of carbon-supported Pd-Co core-shell nanoparticles as oxygen reduction electrocatalysts and their enhanced activity and stability with monolayer Pt decoration. Chem. Mater. 24, 2274-2281 (2012).

31. Ruban, A. V., Skriver, H. L. \& Norskov, J. K. Surface segregation energies in transition-metal alloys. Phys. Rev. B 59, 15990-16000 (1999).

32. Wang, L.-L. \& Johnson, D. D. Predicted trends of core - shell preferences for 132 late transition-metal binary-alloy nanoparticles. J. Am. Chem. Soc. 131, 14023-14029 (2009).

33. Yin, Y. D. et al. Formation of hollow nanocrystals through the nanoscale Kirkendall Effect. Science 304, 711-714 (2004).

34. Zhang, J. et al. Stabilization of platinum oxygen-reduction electrocatalysts using gold clusters. Science 315, 220-222 (2007).

35. Kang, Y. et al. Multimetallic core/interlayer/shell nanostructures as advanced electrocatalysts. Nano Lett. 14, 6361-6367 (2014).

36. Kuttiyiel, K. A. et al. Gold-promoted structurally ordered intermetallic palladium cobalt nanoparticles for the oxygen reduction reaction. Nat. Commun. 5, 5185-5194 (2014).

37. Zhang, P. \& Sham, T. K. Tuning the electronic behavior of Au nanoparticles with capping molecules. Appl. Phys. Lett. 81, 736-738 (2002).

38. Zhang, P. et al. Organosulfur-functionalized $\mathrm{Au}, \mathrm{Pd}$, and $\mathrm{Au}-\mathrm{Pd}$ nanoparticles on 1D silicon nanowire substrates: Preparation and XAFS studies. Langmuir 21, 8502-8508 (2005).

39. Kuhn, M. \& Sham, T. K. Charge redistribution and electronic behavior in a series of Au-Cu alloys. Phys. Rev. B 49, 1647-1661 (1994).

40. Lee, Y. S. et al. Charge redistribution and electronic behavior in Pd-Au alloys. J. Korean Phys. Soc. 37, 451-455 (2000).

\section{Acknowledgements}

This work was supported by the National Science Foundation of China (21306060 21573083), the Program for New Century Excellent Talents in Universities of China (NCET-13-0237) and the Doctoral Fund of Ministry of Education of China (20130142120039). This research used resources of the Center for Functional Nanomaterials, Brookhaven National Laboratory, which is supported by the U.S. Department of Energy, Office of Basic Energy Sciences, under Contract No. DE-SC0012704. Experimental data recording for Fig. 2 was supported by the Energy Materials Center at Cornell $\left(\mathrm{emc}^{2}\right)$, an Energy Frontier Research Center funded by the U.S. Department of Energy, Office of Basic Energy Sciences, under Award No. DE-SC0001086. This work also made use of the facility of the Cornell Center for Materials Research (CCMR) with support from the National Science Foundation Materials Research Science and Engineering Centers (MRSEC) program (Contract No. DMR 1120296). This work also made use of the Cornell High Energy Synchrotron Source (CHESS) which is supported by the National Science Foundation and the National Institutes of Health/National Institute of General Medical Sciences under NSF award DMR-0936384. Some preliminary study was performed at Stanford Synchrotron Radiation Lightsource, a Directorate of SLAC National Accelerator Laboratory supported by the U.S. Department of Energy, Office of Science, Office of Basic Energy Sciences under Contract No. DE-AC02-76SF00515. The authors are grateful to Dr Jianguo Liu from Nanjing University for helping doing the fuel-cell performance and useful discussion and analysis of the data. D. Wang would like to thank Analytical and Testing Center of Huazhong University of Science \& Technology for allowing us to use its facilities.

\section{Author contributions}

D.W., H.L.X. and H.D.A conceived the idea. All authors contributed to the design of the experiments. D.W., S.L and J. W. performed the synthesis and electrochemical tests. R.L. M.K. and H.L.X. performed TEM measurements and analysis. M.A.L., F.L., D.N. performed the synchrotron X-ray measurements and analysis. All authors discussed the results and implications at all stages. D.W., H.L.X. and H.D.A. wrote the paper with assistance from all authors.

\section{Additional information}

Supplementary Information accompanies this paper at http://www.nature.com/ naturecommunications

Competing financial interests: The authors declare no competing financial interests

Reprints and permission information is available online at http://npg.nature.com/ reprintsandpermissions/

How to cite this article: Wang, D. et al. Spontaneous incorporation of gold in palladiumbased ternary nanoparticles makes durable electrocatalysts for oxygen reduction reaction. Nat. Commun. 7:11941 doi: 10.1038/ncomms11941 (2016)

(c) (i) This work is licensed under a Creative Commons Attribution 4.0 International License. The images or other third party material in this article are included in the article's Creative Commons license, unless indicated otherwise in the credit line; if the material is not included under the Creative Commons license, users will need to obtain permission from the license holder to reproduce the material. To view a copy of this license, visit http://creativecommons.org/licenses/by/4.0/ 